\title{
Pengaruh Tutor Teman Sebaya terhadap Minat Belajar Siswa Kelas XI pada Mata Pelajaran Ekonomi di SMA Negeri 8 Kota Jambi
}

\author{
Pratiwi Indah Sari \\ Dosen Program Studi Pendidikan Ekonomi, FKIP UNBARI \\ Correspondence email: ilcapitanojuventus@ rocketmail.com
}

\begin{abstract}
Abstrak: Penelitian ini bertujuan untuk mengetahui gambaran responden mengenai tutor teman sebaya terhadap minat belajar siswa pada mata pelajaran ekonomi kelas XI IPS di SMA Negeri 8 Kota Jambi, dan untuk mengetahui pengaruh tutor teman sebaya terhadap minat belajar siswa pada mata pelajaran ekonomi kelas XI IPS di SMA Negeri 8 Kota Jambi. Berdasarkan analisis data pada hasil penelitian bahwa terdapat pengaruh yang signifikan antara tutor teman sebaya terhadap minat belajar pada mata pelajaran ekonomi kelas XI SMA Negeri 8 Kota Jambi. Pada ANOVA, nilai F = 16,232 dengan $\alpha(\operatorname{sig})=0,002$. Oleh karena $\alpha$ (Sig) $<0,05$, maka regresi dapat digunakan untuk memprediksi tutor teman sebaya pada taraf kepercayaan $95 \%$. Pada coefficient nilai B constant $=68,622$, menyatakan bahwa jika variabel tutor teman sebaya diabaikan, maka minat belajar $=68,622$. Sedangkan, nilai variable untuk tutor teman sebaya (X) adalah 6,292, menyatakan bahwa jika tingkat tutor teman sebaya seperti dilibatkan, maka minat belajar meningkat sekitar 6,292.
\end{abstract}

Kata Kunci: Tutor Teman Sebaya, Minat Belajar

\begin{abstract}
This study aims to determine the description of respondents about peer tutors on student interest in the subjects of economy class XI IPS in SMA Negeri 8 Kota Jambi, and to determine the influence of peer tutors on student interest in the subjects of economy class XI IPS in SMA Negeri 8 Kota Jambi. Based on data analysis on the results of research that there is a significant influence between peer tutors on the interest of learning on the economic subjects of class XI SMA Negeri 8 Kota Jambi. In ANOVA, the value of $F=16.232$ with $\alpha($ sig) $=0.002$. Because $\alpha(S i g)<0.05$, then regression can be used to predict peer tutor at $95 \%$ confidence level. In coefficient the value of B constant $=68,622$, states that if the peer tutor variables are ignored, the interest in learning $=68.622$. Meanwhile, the variable value for peer tutor $(X)$ is 6,292, stating that if the peer-level tutor is involved, the interest in learning increases around 6.292.
\end{abstract}

Keyword: Peer Friends Tutor, Interest Learning.

\section{PENDAHULUAN}

Dalam kegiatan belajar mengajar ada dua hal yang ikut menentukan keberhasilan, yakni pengatur proses belajar mengajar, dan pengajaran itu sendiri. Kedua hal tersebut mempunyai atau saling ketergantungan satu sama lain. Kemampuan mengatur proses belajar mengajar yang baik, akan menciptakan situasi yang memungkinkan anak belajar, sehingga merupakan titik awal keberhasilan pengajaran. Siswa dapat belajar dalam suasana wajar, tanpa tekanan dan dalam kondisi yang merangsang untuk belajar. Dalam kegiatan belajar mengajar siswa memerlukan sesuatu yang memungkinkan dia berkomunikasi secara baik dengan guru, teman, maupun dengan lingkungannya. Kebutuhan akan bimbingan, bantuan, dan perhatian guru, yang berbeda untuk setiap individu siswa.

Saat anak belajar, mereka tentu melakukan kesalahan dalam proses belajarnya, namun pada titik tertentu mereka akan terbiasa melakukan tindakan yang dibutuhkan secara efektif. Anak akan berubah dari seseorang yang tidak bisa mengikuti pelajaran di kelas hingga anak yang terbiasa mengikuti pelajaran di kelas. Hasil ini dilaksanakan, pembelajaran (learning) dapat didefinisikan sebagai pengaruh permanen sebagai prilaku, pengetahuan, dan keterampilan berpikir, yang diperoleh melalui pengalaman, sehingga peserta didik dapat mengalami perubahan baik dalam sikap maupun pengetahuan.

Proses belajar tersebut dilihat dari berhasil atau tidaknya siswa mendapat stimulus maupun respon yang positif terhadap pembelajaran yang berlangsung. Pada akhirnya, proses tersebut dapat dilihat dari minat belajar siswa itu sendiri. Artinya minat merupakan faktor yang sangat penting dalam menentukan hasil belajar siswa. Dengan adanya minat maka rangsangan yang timbul akan meningkatkan semangat dalam diri siswa, maka ia akan mendapatkan kepuasan batin dengan hasil belajar yang baik yang telah dicapai. Sebaliknya, suatu kegiatan yang tidak dilakukan sesuai dengan minat akan menghasilkan hasil belajar yang kurang memuaskan. Tanpa minat yang kuat, sangat sulit bagi seorang siswa untuk mencapai prestasi yang maksimal.

Untuk meningkatkan minat belajar siswa, seorang guru memiliki kewajiban menciptakan pengajaran yang mempu membantu murid lebih kreatif. Strategi yang bisa mengilhami kreativitas antara brainstorming, memberi murid lingkungan yang memicu kreativitas, tidak terlalu mengatur murid, mendorong motivasi internal, mendorong pemikiran fleksibel dan menarik, dan memperkenalkan murid dengan orang-orang kreatif. Maka, dalam meningkatkan 
Pratiwi Indah Sari, Pengaruh Tutor Teman Sebaya terhadap Minat Belajar Siswa Kelas XI pada Mata Pelajaran Ekonomi di SMA Negeri 8 Kota Jambi

pelajaran, seorang guru tidak tidak bisa hanya melalui peningkatan aktivitas guru seorang diri, melainkan aktivitas dengan bantuan teman satu bangku juga diperlakukan. Atau, yang sering disebut juga dengan tutor teman sebaya.

Bantuan yang diberikan teman-teman sebaya pada umumnya dapat memberikan hasil yang cukup baik. Peran teman sebaya dapat menumbuhkan dan membangkitkan persaingan hasil belajar secara sehat, karena siswa yang dijadikan tutor, eksistensinya diakui oleh teman sebaya. Dalam satu kelas selisih usia antara siswa satu dengan siswa yang lain tentu relatif kecil atau hampir sama, sehingga dalam satu kelas terdapat kelompok teman sebaya yang saling berinteraksi antara siswa satu dengan yang lain sehingga akan terbentuk pola tingkah laku yang dipakai dalam pergaulan mereka. Dalam interaksi tersebut tidak menutup kemungkinan antar siswa satu dengan siswa yang lain saling membantu dan membutuhkan dalam pembelajaran untuk memperoleh hasil belajar yang lebih baik.

Tutoring pada dasarnya adalah pelatihan kognitif antara pakar dengan pemula. Tutoring bisa terjadi antara orang dewasa dan anak-anak, atau antara anak yang lebih pandai dengan anak yang kurang pandai. Toturing yang individual adalah strategi yang efektif yang menguntungkan banyak murid, terutama mereka yang kurang pandai dalam suatu mata pelajaran. Pembelajaran dengan tutor teman sebaya ini dilakukan atas dasar bahwa ada sekelompok siswa yang lebih mudah bertanya, lebih terbuka dengan teman sendiri dibandingkan dengan gurunya. Dengan adanya tutor teman sebaya siswa yang kurang aktif menjadi aktif karena tidak malu lagi untuk bertanya dan mengeluarkan pendapat secara bebas, sebagaimana tutor teman sebaya ini adalah wujud apa yang terpendam dalam hatinya, dan khayalannya.

Berdasarkan observasi awal yang dilakukan oleh peneliti tergambar bahwa respon siswa terhadap teman sebaya di SMA Negeri 8 Jambi Kota Jambi diperoleh informasi bahwa masih kurangnya teman bertanya sesama teman tentang pembelajaran. Masih jarangnya siswa mengajari siswa lainnya yang mengalami kesulitan dalam belajar, masih sedikitnya siswa memberi saran terhadap tugas siswa, masih jarangnya siswa bertanya kesulitan belajar dengan teman lainnya, masih jarangnya teman menjawab dan memecahkan masalah teman sebayanya serta masih jarangnya, teman mengajari teman lainnya dalam belajar. Dari hal tersebut dapat diketahui bahwa masih rendahnya tutor teman sebaya yang ada di SMA Negeri 8 Jambi Kota Jambi.

Pembelajaran teman/tutor sebaya adalah pembelajaran yang terpusat pada siswa, dalam hal ini siswa belajar dari siswa lain yang memiliki status umur, kematangan/harga diri yang tidak jauh berbeda dari dirinya sendiri. Sehingga anak tidak merasa begitu terpaksa untuk menerima ide-ide dan sikap dari "gurunya" yang tidak lain adalah teman sebayanya itu sendiri. Dalam tutor sebaya, teman sebaya yang lebih pandai memberikan bantuan belajar kepada teman-teman sekelasnya di sekolah. Menurut Suherman (2003:277) menyatakan bahwa "Bantuan belajar oleh teman sebaya dapat menghilangkan kecanggungan". Bahasa teman sebaya lebih mudah dipahami, selain itu dengan teman sebaya tidak ada rasa enggan, rendah diri, malu, dan sebagainya, sehingga diharapkan siswa yang kurang paham tidak segan-segan untuk mengungkapkan kesulitan-kesulitan yang dihadapinya.

Sukmadinata (2007:66) menyatakan bahwa "Bantuan belajar oleh teman sebaya dapat menghilangkan kecanggungan". Bahasa teman sebaya lebih mudah dipahami, selain itu dengan teman sebaya tidak ada rasa enggan, rendah diri, malu, dan sebagainya, sehingga diharapkan siswa yang kurang paham tidak segan-segan untuk mengungkapkan kesulitan-kesulitan yang dihadapinya. Sedangkan, Djamarah (2010:25) menjelaskan bahwa "Tutor adalah siswa yang mempunyai umur atau usia yang hampir sama atau sebaya". Istilah ini untuk membedakan "tutor serumah", yaitu pengajaran yang dilakukan oleh orang tua, kakak, atau anggota keluarga lainnya yang bertempat tinggal serumah dengan siswa tersebut. Selain itu dapat juga untuk membedakan dengan tutorial yang dilakukan oleh staf pengajar yang lain bukan dari siswa.

Septya (2010:2) menyatakan bahwa "Peserta didik di kelas tertentu yang memiliki kemampuan di atas rata-rata anggotanya yang memiliki tugas untuk membantu kesulitan anggota dalam memahami materi ajar". Kalau biasanya guru adalah lebih tua dan muridnya lebih muda. Dengan menggunakan metode tutor sebaya diharapkan setiap anggota lebih mudah dan leluasa dalam menyampaikan masalah yang dihadapi, sehingga peserta didik yang bersangkutan dapat terpacu semangatnya untuk mempelajari materi ajar dengan baik. Seorang tutor hendaknya memiliki kriteria: (a) Memiliki kemampuan akademis, (b) Menjalin kerjasama, (c) Meningkatkan motivasi belajar, (d) Memiliki sikap toleransi, dan (d) Memiliki rasa tanggungjawab yang tinggi.

Ahmadi, dkk (2004:83), menyatakan bahwa 'Tidak adanya minat seseorang terhadap suatu pelajaran akan menimbulkan kesulitan belajar". Belajar dengan minat akan mendorong siswa belajar dengan baik dari pada belajar tanpa minat. Namun demikian, minat tanpa adanya usaha yang baik maka belajar juga akan sulit untuk berhasil. Sementara, Putra (2011:21), menyatakan bahwa "Minat yang kuat akan menimbulkan usaha yang gigih serius dan tidak mudah putus asa dalam menghadapi tantangan, jika seseorang siswa ingin memiliki rasa ingin belajar, maka siswa akan cepat mengerti dan mengingatnya". Fungsi minat bagi kehidupan anak, salah satunya yaitu minat sebagai pendorong tenaga yang kuat serta prestasi selalu dipengaruhi oleh jenis dan intensitas minatnya.

Dengan demikian, dapat dikatakan bahwa minat belajar adalah perhatian, rasa suka dan rasa ketertarikan seseorang (siswa) terhadap belajar yang ditunjukkan dengan adanya partisipasi, keinginan siswa untuk belajar dengan baik, dan perhatian siswa dalam materi pelajaran secara aktif dan serius. Sementara, Dimyati, dkk (2005:60) 
Pratiwi Indah Sari, Pengaruh Tutor Teman Sebaya terhadap Minat Belajar Siswa Kelas XI pada Mata Pelajaran Ekonomi di SMA Negeri 8 Kota Jambi

menyebutkan beberapa indikator dalam mengetahui minat belajar dalam diri seseorang atau siswa yang meliputi perasaan senang, ketertarikan siswa, perhatian.

Pelajaran akan berjalan dengan lancar apabila ada minat. Anak-anak malas, tidak belajar, gagal karena tidak ada minat. Dalam kegiatan belajar, minat mempunyai peranan yang sangat penting. Bila seseorang siswa tidak memiliki minat dan perhatian besar terhadap suatu objek yang dipelajari maka sulit diharapkan siswa tersebut akan tekun dan memperoleh hasil yang baik dari belajarnya. Sebaliknya, apabila siswa tersebut belajar dengan minat dan perhatian yang besar terhadap yang mempengaruhi suatu obejek yang dipelajari, maka hasil yang diperoleh lebih baik.

Dengan demikian, dalam proses pembelajaran, seorang guru tidak dapat hanya mengandalkan pada kemampuan tingkat intelegensi para siswanya. Hal ini dikarenakan, tidak semua siswa memiliki IQ dan ESQ yang sama satu dengan yang lainnya. Maka, siswa dapat mengandalkan teman sebangkunya dalam memahami materi pembelajaran yang diberikan oleh guru. Sebab, seorang tidak dapat mengawasi dan membimbing siswanya satu persatu. Adapun cara yang dapat dilakukan oleh guru adalah memberikan kebebasan kepada para siswa untuk dapat mengembangkan wawasan dan pengalaman mereka dalam bentuk kerjasama antar sesama teman sebayanya. Meskipun demikian, tutor disini hanya berperan sebagai penerapan kerjasama antar siswa dalam proses pembelajaran.

Dengan menggunakan cara ini maka siswa yang memiliki minat belajar yang rendah akan lebih termotivasi untuk belajar. dapat dijelaskan bahwa dengan adanya penerapan kebijakan seorang guru dalam memberikan kebebasan siswa dalam belajar seperti tutor teman sebaya akan meningkatkan maupun merubah minat belajar siswa itu sendiri. Hal ini dikarenakan, siswa yang memiliki minat belajar yang rendah akan berani untuk bertanya dengan teman sebayanya daripada dengan gurunya.

\section{METODE}

Dalam melakukan penelitian dan untuk melihat hasil penelitian dari perhitungan-perhitungan instrumen yang digunakan, maka digunakan metode analisis data. Adapun metode analisis data yang digunakan dalam penelitian ini adalah metode analisis regresi linear sederhana. Dimana, dalam menganalisis pengukuran yang menguji pengaruh tutor teman sebaya terhadap minat belajar siswa. Dengan menggunakan estimasi : $\mathrm{Y}=\mathrm{a}+\mathrm{b}_{1} \mathrm{X}_{1}+\mathrm{e}$. Dalam penelitian, tingkat pengukuran dan pengaruh antar variabel dapat diukur dengan menggunakan uji antara satu variabel instrumen dengan variabel instrumen lainnya. Dimana, hal ini dilakukan untuk melihat apakah ada pengaruh atau tidaknya variabel-variabel yang digunakan tersebut.

Untuk mengetahui gambaran-gambaran yang ada dalam penyebaran kuesioner yang dilakukan maka digunakan analisis deskriptif. Deskriptif yang oleh Syekh (2011:15) dijelaskan sebagai suatu metode dalam meneliti suatu kelompok manusia, suatu objek, suatu kondisi suatu sistem pemikiran dengan suatu tujuan untuk membuat deskripsi, gambaran yang sistematis sesuai fakta yang sedang diselidiki. Selanjutnya, dikatakan bahwa jika kita ingin meneliti satu dua aspek yang sudah dipetakan maka kita harus masuk kedalam penelitian yang lebih mendalam.

Dengan menggunakan variabel tutor teman sebaya $(\mathrm{X})$ dan minat belajar $(\mathrm{Y})$ siswa, maka dalam analisa data penelitian akan menggunakan uji validitas dan uji reliabilitas dalam uji persyaratan data yang dilakukan. Sementara, untuk analisisnya sendiri cukup menggunakan uji analisis regresi linier sederhana karena variabel yang digunakan hanya terdiri dari tutor teman sebaya $(\mathrm{X})$ dan minat belajar $(\mathrm{Y})$.

\section{HASIL DAN PEMBAHASAN}

Tanggapan responden atau siswa terhadap tutor teman sebaya dan minat belajar siswa di SMA Negeri 8 Kota Jambi dapat dilihat dari pilihan kriteria jawaban setiap item pertanyaan yang telah dikembangkan berdasarkan indikator dari variabel tutor teman sebaya dan minat belajar siswa yang sesuai di SMA Negeri 8 Kota Jambi.

Tabel 1. Distribusi Frekuensi Skor Variabel Tutor Teman Sebaya (X)

\begin{tabular}{|c|c|c|c|c|c|}
\hline No & Indikator & Skor Total & Rerata & TCR & Keterangan \\
\hline 1. & Kemampuan Akademis & 466,75 & 3,43 & 68,64 & Cukup Baik \\
\hline 2. & Menjalin Kerjasama & 316,25 & 3,48 & 69,63 & Cukup Baik \\
\hline 3. & Motivasi Belajar & 408 & 3,00 & 60,00 & Cukup Baik \\
\hline 4. & Toleransi & 506 & 3,72 & 74,41 & Cukup Baik \\
\hline 5. & Kerjasama & 452 & 3,32 & 66,47 & Cukup Baik \\
\hline & Jumlah & 429,8 & 3,39 & 67,68 & Cukup Baik \\
\hline
\end{tabular}

Sumber : Data Diolah, Tahun 2017. 
Pratiwi Indah Sari, Pengaruh Tutor Teman Sebaya terhadap Minat Belajar Siswa Kelas XI pada Mata Pelajaran Ekonomi di SMA Negeri 8 Kota Jambi

Tabel 2. Distribusi Frekuensi Skor Minat Belajar (Y)

\begin{tabular}{|c|c|c|c|c|c|}
\hline No & Indikator & Skor Total & Rerata & TCR & Keterangan \\
\hline 1. & Perasaan Senang & 500,20 & 3,68 & 73,86 & Cukup Baik \\
\hline 2 & Ketertarikan & 511,60 & 3,76 & 75,24 & Cukup Baik \\
\hline 3. & Perhatian & 507,75 & 3,73 & 74,67 & Cukup Baik \\
\hline & Jumlah & 506,52 & 3,72 & $\mathbf{7 4 , 4 9}$ & Cukup Baik \\
\hline
\end{tabular}

Sumber: Data Diolah, 2017.

Pengujian normalitas data dalam suatu penelitian secara ilmiah dapat dilakukan dengan menggunakan teknik Uji Kolmogorov Smirnov-Test (Uji K-S) sebagai pengukur terhadap instrumen penelitian yang dijadikan tolok ukur dalam suatu penelitian.

Tabel 3 Hasil Uji Normalitas Data One-Sample Kolmogorov-Smirnov Test

\begin{tabular}{|ll|r|r|}
\hline & & TS & MB \\
\hline N & & 136 & 136 \\
& Mean & 58.1912 & 52.2353 \\
Most Extreme Differences & Std. Deviation & $1.02686 \mathrm{E} 1$ & .082 \\
& Absolute & .082 & .039 \\
& Positive & -.082 & .43299 \\
Kolmogorov-Smirnov Z & Negative & .957 & .050 \\
Asymp. Sig. (2-tailed) & & .318 & -.101 \\
\hline
\end{tabular}

a. Test distribution is Normal.

Hubungan (korelasi) antara variabel tutor teman sebaya (X) terhadap minat belajar (Y) di SMA Negeri 8 Kota Jambi. Untuk menguji Hipotesis akan diuji dengan menggunakan alat Statistik Koefisien Korelasi. Dari struktur analisis linear akan dilakukan analisis untuk mengetahui tingkat signifikansi dan nilai koefisien dari masing-masing variabel independen terhadap variabel dependen untuk substruktur dari analisis regresi linear sederhana.

Tabel 4. Hasil Analisis Estimasi Regresi Variabel Tutor Teman Sebaya (X) Terhadap Minat Belajar (Y) Coefficients $^{\mathrm{a}}$

\begin{tabular}{|c|c|c|c|c|c|c|}
\hline \multirow{2}{*}{\multicolumn{2}{|c|}{ Model }} & \multicolumn{2}{|c|}{ Unstandardized Coefficients } & \multirow{2}{*}{$\frac{\text { Standardized Coefficients }}{\text { Beta }}$} & \multirow[b]{2}{*}{$\mathrm{t}$} & \multirow[b]{2}{*}{ Sig. } \\
\hline & & B & Std. Error & & & \\
\hline \multirow[t]{2}{*}{1} & (Constant) & 68.632 & 4.259 & & 14.356 & .000 \\
\hline & TTS & 6.292 & .255 & .276 & 5.255 & .000 \\
\hline
\end{tabular}

a. Dependent Variable: HB

\section{Gambaran Tutor Teman Sebaya dan Minat Belajar Siswa Kelas XI di SMA Negeri 8 Kota Jambi}

Berdasarkan perhitungan diketahui bahwa tutor teman sebaya di SMA Negeri 8 Kota Jambi yang terdiri dari kemampuan akademis, menjalin kerjasama, motivasi belajar, toleransi, kerjasama termasuk kategori cukup baik, seperti dikemukakan oleh 136 orang responden atau sebesar 67,83\%. Hal ini berarti tutor teman sebaya yang ada di SMA Negeri 8 Kota Jambi dapat dinyatakan cukup baik. Sementara, pada variabel minat belajar siswa kelas XI di SMA Negeri 8 Kota Jambi berdasarkan perhitungan yang telah dilaksanakan, dimana variabel ini sendiri terdiri dari perasaan senang, ketertarikan, dan perhatian termasuk kategori baik, seperti dikemukakan oleh 136 orang responden atau sebesar 93,11\%. Hal ini berarti minat belajar siswa yang ada di kelas XI SMA Negeri 8 Kota Jambi dapat dinyatakan baik.

\section{Pengaruh Tutor Teman Sebaya dan Minat Belajar Siswa Kelas XI di SMA Negeri 8 Kota Jambi}

Berdasarkan hasil perhitungan diperoleh hasil model summary $\mathrm{R}=1,265$ dan $\mathrm{R}$ Square $=0,663$. Pada coefficient, nilai $\mathrm{t}=5,255$ dengan $\alpha(\mathrm{sig})=0,000$. Oleh karena $\alpha(\mathrm{Sig})<0,05$, maka regresi dapat digunakan untuk memprediksi tutor teman sebaya pada taraf kepercayaan 95\%. Pada coefficient nilai B constant $=68,622$, menyatakan bahwa jika variabel tutor teman sebaya diabaikan, maka minat belajar $=68,622$. Sedangkan, nilai variabel untuk tutor 
teman sebaya (X) adalah 6,292, menyatakan bahwa jika tingkat tutor teman sebaya seperti dilibatkan, maka minat belajar meningkat sekitar 6,292.

Sukmadinata (2007:66) menyatakan bahwa "Bantuan belajar oleh teman sebaya dapat menghilangkan kecanggungan". Bahasa teman sebaya lebih mudah dipahami, selain itu dengan teman sebaya tidak ada rasa enggan, rendah diri, malu, dan sebagainya, sehingga diharapkan siswa yang kurang paham tidak segan-segan untuk mengungkapkan kesulitan-kesulitan yang dihadapinya (Sukmadinata, 2007:66). Dengan kata lain, tutor teman sebaya artinya siswa yang mengalami kesulitan belajar diberi bantuan oleh teman-teman mereka sekelas yang punya umur sebaya dengan dia.

Menurut penelitian Magdalena (2013:21-31) dengan tutor sebaya dapat membantu kegiatan belajar siswa dengan memanfaatkan teman sekelas yang mempunyai kemampuan lebih untuk membantu temannya dalam melaksanakan suatu kegiatan atau memahami suatu konsep memiliki motivasi tinggi untuk meraih prestasi akademis yang baik, memiliki sikap toleransi, tenggang rasa, dan ramah dengan sesama, memiliki motivasi tinggi untuk menjadikan kelompok diskusinya sebagai yang terbaik, bersikap rendah hati, pemberani, bertanggung jawab, dan membantu sesamanya yang mengalami kesulitan sehingga minat belajar teman lainnya meningkat.

\section{SIMPULAN}

1. Tutor teman sebaya mendapat nilai capaian responden sebesar 67,83 dengan kategori cukup baik, sementara minat belajar diperoleh dengan nilai capaian responden sebesar 74,49 dengan kategori cukup baik.

2. Berdasarkan analisis data pada hasil penelitian bahwa terdapat pengaruh yang signifikan antara tutor teman sebaya terhadap minat belajar pada mata pelajaran ekonomi di kelas XI SMA Negeri 8 Kota Jambi.

\section{Saran}

Tutor teman sebaya terbukti memberikan pengaruh yang signifikan terhadap minat belajar siswa pada mata pelajaran ekonomi di kelas XI SMA Negeri 8 Kota Jambi, maka setidaknya guru yang menjadi pihak pertama di kelas harus lebih memperhatikan interaksi antara siswa, sehingga para siswa dapat saling membantu dalam kegiatan pembelajaran.

\section{DAFTAR PUSTAKA}

Ahmadi, Abu dan Widodo Supriyono. 2013. Psikologi Umum. Jakarta : PT. Rineka Cipta.

Djamarah, Jaini. 2010. Strategi Belajar Mengajar. Jakarta : PT. Renika Cipta.

Septya, Suhe Sawali. 2010. Diskusi Kelompok Terbimbing Tutor Sebaya. Bandung : Remaja Rosda Karya

Syekh, Said. 2011. Pengantar Statistik Ekonomi dan Sosial. Jakarta : Gaung Persada. 